\title{
Preparation and Spectroscopic Studies of Cadmium(II), Zinc(II), Mercury(II) and Vanadium(IV) Chelates Azo Ligand Derived from 4-Methyl-7-hydroxycoumarin
}

\author{
Bayader Fathil Abass, Taghreed Mohy Al-Deen Musa, and Mahmoud Najim Abid Al-Jibouri* \\ Department of Chemistry, College of Science, Mustansiriyah University, Baghdad, Iraq
}

\author{
* Corresponding author: \\ tel: $+964-7713460946$ \\ email:mahmou_inor71@uomustansiriyah.edu.iq \\ Received: January 11, 2021 \\ Accepted: May 18, 2021
}

DOI: $10.22146 /$ ijc. 63032

\begin{abstract}
The present paper demonstrates the synthesis and characterization of some transition elements complexes derived from (E)-7-hydroxy-6-((4methoxyphenyl)diazenyl)-4-methyl-2H-chromen-2-one. The ligand was prepared in the general route of azo dyes by coupling the diazonium salt of 4methoxyaniline with 4-methyl-7-hydroxycoumarin in sodium hydroxide 10\% $(w / v)$ solution. The azo ligand was identified on the basis of elemental analyses, MS, H-NMR and FT-IR spectra. The products of complexes with the new azo dye were isolated by the direct reactions of the metal chlorides of cadmium(II), zinc(II), vanadium(IV) and mercury(II) ions with the alkaline solution of free ligand to afford the colored in the following formulas, complexes[ $\left[\mathrm{ML}_{2}\right] 2 \mathrm{H}_{2} \mathrm{O}$ formula, $M=C d(I I)$ and $Z n(I I)$. However the vanadium(IV) complex was square pyramid in $\left[\mathrm{VOL}_{2}\right] \mathrm{SO}_{4} 2 \mathrm{H}_{2} \mathrm{O}$ chemical formula. As well as the tetrahedral environment was suggested for mercury(II) complex in formula $\left[\mathrm{HgL}_{2}\right]$. The time and mole ratio factors were studied to obtain the optimized conditions of metal complexes formations and the observed data investigated the deprotonation of the azo-dye at $\mathrm{pH}$ to range (7-7.5) with $30 \mathrm{~min}$ as time of reaction to get pure metal chelates. The TG-DSC study confirmed the thermal stability of complexes at a wide range of average heating in inert gas of analysis and the results observed from loss weight percent investigated the proposed structures of the prepared metal complexes.
\end{abstract}

Keywords: azo ligands; metal complexes of coumarin; spectroscopic studies

\section{- INTRODUCTION}

The major branch of coordination chemistry has been partially allocated with the azo dyes of 4hydroxycoumarine and their derivatives [1-2]. The inorganic complexes of chromen-2-one rings mainly could possess applications in catalysis, manufacturing of dyes and pharmaceutical drugs [3-5]. The pentagonal and hexagonal coordination complexes of dyes involving immine and hydroxyl groups have shown a wide range of applications in the diodes and solar cells fields [6-7]. The common coordination compounds derived from azo dyes of chromen-2-one have interested in wide spectrum of applications in the emission studies like fluorescence and phosphorescence [8-10].
Recently the researchers have encouraged enhancing the electronic and geometrical features of complexes of azo dyes that they would have exhibited nonlinear optical elements and printing systems [11-14]. All the above mentioned about the development of coumarin azo dyes with their chelation ability afford us to prepare and characterize new azo dye complexes of $\mathrm{Zn}(\mathrm{II}), \mathrm{Cd}(\mathrm{II}), \mathrm{V}(\mathrm{IV})$ and $\mathrm{Hg}(\mathrm{II})$ derived from (E)-7hydroxy-6-((4-methoxyphenyl)diazenyl)-4-methyl-2Hchromen-2-one.

\section{- EXPERIMENTAL SECTION}

\section{Materials}

The starting 4-methoxyaniline and 4-methyl-7hydroxycoumarin and 4-methoxyaniline were supplied 
via Merck Company and the metal salts of $\mathrm{VOSO}_{4} \cdot 5 \mathrm{H}_{2} \mathrm{O}$, $\mathrm{CdCl}_{2} \cdot 2 \mathrm{H}_{2} \mathrm{O}, \mathrm{ZnCl}_{2}, \mathrm{CdCl}_{2}$ and $\mathrm{HgCl}_{2}$ were supplied from Quaternary Group Merck Chemicals Companies and used as supplied without purification.

\section{Instrumentation}

The melting points temperature of the coumarin derivatives and metal complexes were determined on the Stuart melting point apparatus. The molecular weights of the ligand and some selected metal complexes were measured their mass spectra on a Shimadzu model GC MS QP 1000EX at college of science, Mustansiriyah University. The electronic spectra of ligand and its complexes in ethanol and DMSO solvents was determined with UV-1800 Shimadzu spectrometer apparatus. The nuclear magnetic resonance spectroscopy was carried out in d6-DMSO solvent on Bruker-500 MHz NMR spectrometer. The main features of vibration frequencies of azo dye ligand and its metal complexes were scanned on Shimadzu FT-IR spectroscopy in the range (4000-200) $\mathrm{cm}^{-1}$. The $\mathrm{pH}$ of the solutions was checked using a Jenway $3020 \mathrm{pH}$ meter. Furthermore, the percentages of metal ions were determined with GBC 933 model FAAS at Ministry of Industry, Ibn-Cina company, Baghdad, Iraq.

\section{Procedure}

\section{Synthesis of azo ligand}

The azo dye was synthesized according to the modified classical procedure established in literature, by dissolving ( $1.83 \mathrm{~g}, 0.01 \mathrm{mmol}$ ) from 4-methoxyaniline in hot distilled water $(10 \mathrm{~mL})$ then followed by an addition of $36 \%(\mathrm{v} / \mathrm{v}) \mathrm{HCl}(5 \mathrm{~mL})$. To this solution, a cooled aqueous solution of sodium nitrite $(0.45 \mathrm{~g}, 5 \mathrm{mmol})$ was added by maintaining the temperature of the reaction at $0{ }^{\circ} \mathrm{C}$. The formed diazonium salt was gradually added to an alkaline solution of 4-methyl-7-hydroxycoumarin $(0.02 \mathrm{~mol}, 3.90 \mathrm{~g})$ with stirring for $30 \mathrm{~min}$, after that the resulting solution was neutralized to $\mathrm{pH}$ of about 6.5 by addition drops of $10 \% \mathrm{NaOH}$. The dark orange crude was then filtered, washed several times with water and ethanol, then dried. The re-crystallization from hot ethanol afforded dark orange crystals of azo dye ligand, L, Scheme (1).<smiles>COc1ccc(N)cc1</smiles><smiles>COc1ccc(/C=N/c2cc3c(C)cc(=O)oc3cc2O)cc1</smiles>

Scheme 1. Synthesis of azo dye, HL

\section{Synthesis of metal complexes}

The metal complexes were prepared by dissolving $\mathrm{ZnCl}_{2}(10 \mathrm{mmol}, 1.45 \mathrm{~g})$ or $\mathrm{CdCl}_{2} \cdot 2 \mathrm{H}_{2} \mathrm{O}(1 \mathrm{mmol}, 1.118 \mathrm{~g})$ in $(15 \mathrm{~mL})$ hot water and ethanolic solution of $(20 \mathrm{mmol}$, $1.44 \mathrm{~g}$ ) of azo dye, $\mathrm{L}$. The mixture was stirred on water bath for $1 \mathrm{~h}$ then red precipitates of $\mathrm{ZnL}$ and $\mathrm{CdL}$ complexes were separated and filtered off. The $\mathrm{Hg}$ (II) complex was prepared by mixing $(10 \mathrm{mmol}, 1.45 \mathrm{~g})$ of azo dye in $(15 \mathrm{~mL})$ hot ethanol with $(10 \mathrm{mmol}, 0.272 \mathrm{~g})$ in $(10 \mathrm{~mL})$ hot water with stirring on a water bath for $2 \mathrm{~h}$, the white off separated precipitate was filtered of and dried in oven at $90{ }^{\circ} \mathrm{C}$. However, the vanadium(IV) complex was isolated in its solid state from oxovanadium sulfate penta hydrate after adjusting the mole ratios 1:2 of (M:L) with respect to dissolving $\mathrm{VOSO}_{4} \cdot 5 \mathrm{H}_{2} \mathrm{O}$ in $(15 \mathrm{~mL})$ hot water with $(20 \mathrm{mmol}, 1.45 \mathrm{~g})$ of azo dye then refluxed the mixture for $2 \mathrm{~h}$. The brown precipitate was filtered, dried in air then washed several times with hot ethanol and diethyl ether, Table 1.

\section{- RESULTS AND DISCUSSION}

\section{Physical Properties and Elemental Analyses}

Table 1 list the main physical properties of ligand and its complexes and show the thermal stability of almost complexes through the elevated their decomposition points. All the complexes are colored and sparingly soluble in most organic solvents except DMSO and DMF. The micro-analyses (C.H.N.) confirm the suggested chemical formula for all complexes beside the structure of azo dye. The calculation of mole ratios was in good agreement of their formation procedure and 
Table 1. Some physical properties and elemental analyses of Azo dye and its complexes

\begin{tabular}{|c|c|c|c|c|c|c|c|}
\hline Compound & $\begin{array}{c}\text { Molecular Weight }(\mathrm{g} / \mathrm{mol}) \\
\text { Formula }\end{array}$ & Color & M.P. $\left({ }^{\circ} \mathrm{C}\right)$ & $\begin{array}{l}\text { \%C Found } \\
\text { (Calc.) }\end{array}$ & $\begin{array}{l}\text { \%H Found } \\
\text { (Calc.) }\end{array}$ & $\begin{array}{l}\text { \%N Found } \\
\text { (Calc.) }\end{array}$ & $\begin{array}{l}\text { \%M Found } \\
\text { (Calc.) }\end{array}$ \\
\hline $\mathrm{HL}$ & $\begin{array}{c}310.09 \\
\mathrm{C}_{17} \mathrm{H}_{14} \mathrm{~N}_{2} \mathrm{O}_{4}\end{array}$ & Dark brown & $178-180$ & $\begin{array}{c}65.00 \\
(65.81)\end{array}$ & $\begin{array}{c}4.22 \\
(4.55)\end{array}$ & $\begin{array}{c}8.88 \\
(9.03)\end{array}$ & -- \\
\hline $\mathrm{ZnL}$ & $\begin{array}{c}683.03 \\
\mathrm{C}_{34} \mathrm{H}_{26} \mathrm{ZnN}_{4} \mathrm{O}_{8}\end{array}$ & Red & $>288$ & $\begin{array}{c}57.90 \\
(58.232)\end{array}$ & $\begin{array}{c}3.49 \\
(3.89)\end{array}$ & $\begin{array}{l}10.11 \\
(9.36)\end{array}$ & $\begin{array}{c}7.99 \\
(9.22)\end{array}$ \\
\hline $\mathrm{CdL}$ & $\begin{array}{c}732.22 \\
\mathrm{C}_{34} \mathrm{H}_{28} \mathrm{CdN}_{4} \mathrm{O}_{10}\end{array}$ & Orange & $>300$ & $\begin{array}{c}52.21 \\
(53.33)\end{array}$ & $\begin{array}{c}4.80 \\
(3.90)\end{array}$ & $\begin{array}{c}9.04 \\
(10.01)\end{array}$ & $\begin{array}{c}15.38 \\
(16.22)\end{array}$ \\
\hline $\mathrm{HgL}$ & $\begin{array}{c}820.53 \\
\mathrm{C}_{34} \mathrm{H}_{26} \mathrm{HgN}_{4} \mathrm{O}_{8}\end{array}$ & Brown & $277-279$ & $\begin{array}{c}55.22 \\
(56.11)\end{array}$ & $\begin{array}{c}3.22 \\
(3.99)\end{array}$ & $\begin{array}{l}10.80 \\
(9.82)\end{array}$ & \\
\hline VOL & $\begin{array}{c}746.79 \\
\mathrm{C}_{34} \mathrm{H}_{30} \mathrm{~N}_{4} \mathrm{SO}_{14} \mathrm{~V}\end{array}$ & Dark brown & $>295$ & $\begin{array}{c}55.33 \\
(56.73) \\
\end{array}$ & $\begin{array}{c}5.33 \\
(5.90) \\
\end{array}$ & $\begin{array}{c}12.60 \\
(11.99)\end{array}$ & $\begin{array}{c}15.44 \\
(16.30)\end{array}$ \\
\hline
\end{tabular}

stoichiometric and it is based on flame atomic absorption data. The flame atomic absorption spectroscopy for metal contents (M\%) in the solid complexes are experimentally determined through standard addition method and the observed analyses are in good agreement with the calculated data confirming the structures of all the prepared complexes. However the molar conductivity measurements reveals that all complexes do not show electrolytic nature [15], except vanadium(IV) complex solution in DMF that exhibits conductivity motion due to the presence of sulfate counter ion in the structure.

\section{Mass Spectra}

The mass spectrum of azo-dye ligand showed peak at molecular ion $m / e=310$ which indicates the unstable molecular weight of the expected $\mathrm{C}_{17} \mathrm{H}_{14} \mathrm{~N}_{2} \mathrm{O}_{4}$ formula due to losing methoxy and methyl groups in the gas-phase of GC conditions for the MS spectra then confirms formation of the azo dye [13]. The peaks observed at around $m / e=116$ and 89 would be resulted from cleavage of chromen ring and points of $-\mathrm{CH}_{3}$ and $-\mathrm{OH}$ respectively [12]. As well as the mass spectrum of vanadium (II) complex shows weak intensity peak at 747 that is allocated to the molecular ion of complex in the gas phase $[14,17]$.

\section{NMR Spectra}

The $\mathrm{H}$ and ${ }^{13} \mathrm{C}-\mathrm{NMR}$ were displayed only for the azo dye with chemical shifts in (ppm) units and are relative to residual proton solvent signals. The spectrum of the ligand is in a good agreement with the number of protons and their assignments of nuclear spins of Ar-H and methyl protons. The ${ }^{1} \mathrm{H}-\mathrm{NMR}$ spectrum of the ligand, Fig. 1 shows a singlet signal at $\delta(7.9-8.99)$ ppm corresponding to the $-\mathrm{C}=\mathrm{C}-\mathrm{H}$ of chromen ring. The peak showed at around $\delta(14.50)$ ppm was also recorded in the ligand spectrum, due to the $-\mathrm{OH}$ proton that is directly attached to $\mathrm{C} 7 \mathrm{of}$ chromen ring. The doublet of doublet peaks at around $\delta(12.45)$ ppm reflects mainly the spin coupling of aromatic protons adjacent to each other in aromatic substituted [12-13]. Furthermore, the aliphatic protons of $-\mathrm{CH}_{3}$ groups attached at C-4 were resonated at around 4.43 .

The ${ }^{13} \mathrm{C}$-NMR spectrum of azo ligand showed multiple peaks at $75 \mathrm{ppm}$ related to $-\mathrm{CH} 3$ aliphatic carbon atom and $96 \mathrm{ppm}$ related to $-\mathrm{C}=\mathrm{OH}$ moiety [1213]. The peaks at $125-135 \mathrm{ppm}$ may be related to resonance of aromatic carbon atoms while the deshielded $-\mathrm{C}-\mathrm{N}=\mathrm{N}-$ and $-\mathrm{C}=\mathrm{C}-$ of coumarin may be assigned to effect of withdrawing groups and showed at 145-165 ppm, respectively. As well as the H-NMR spectrum of CdL complex displayed remarkable changes in some resonated aromatic protons and disappearance of $-\mathrm{OH}$ moiety. These data of NMR confirmed the coordination of $\mathrm{Cd}(\mathrm{II})$ ion with the HL azo dye through $-\mathrm{C}=\mathrm{N}-$ and $\mathrm{OH}$ with deprotonation in the chelation reaction. As well as the deshielded protons of $-\mathrm{HC}=\mathrm{CH}-$ of chromene ring and hydrated water molecules was download shifted due to the electron donation of the active site toward the empty orbitals of Cd(II) ion [16-17]. 


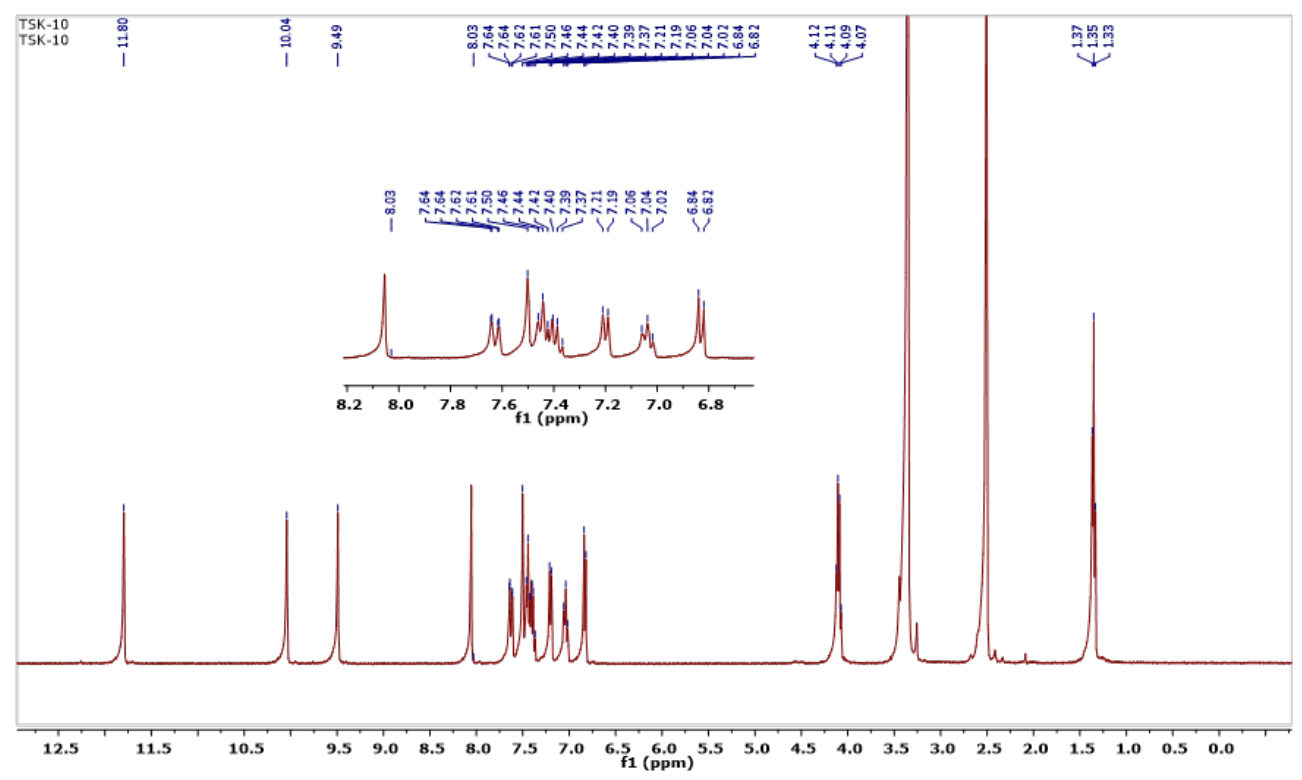

Fig 1. H NMR of azo ligand in DMSO- $d_{6}$ solvent

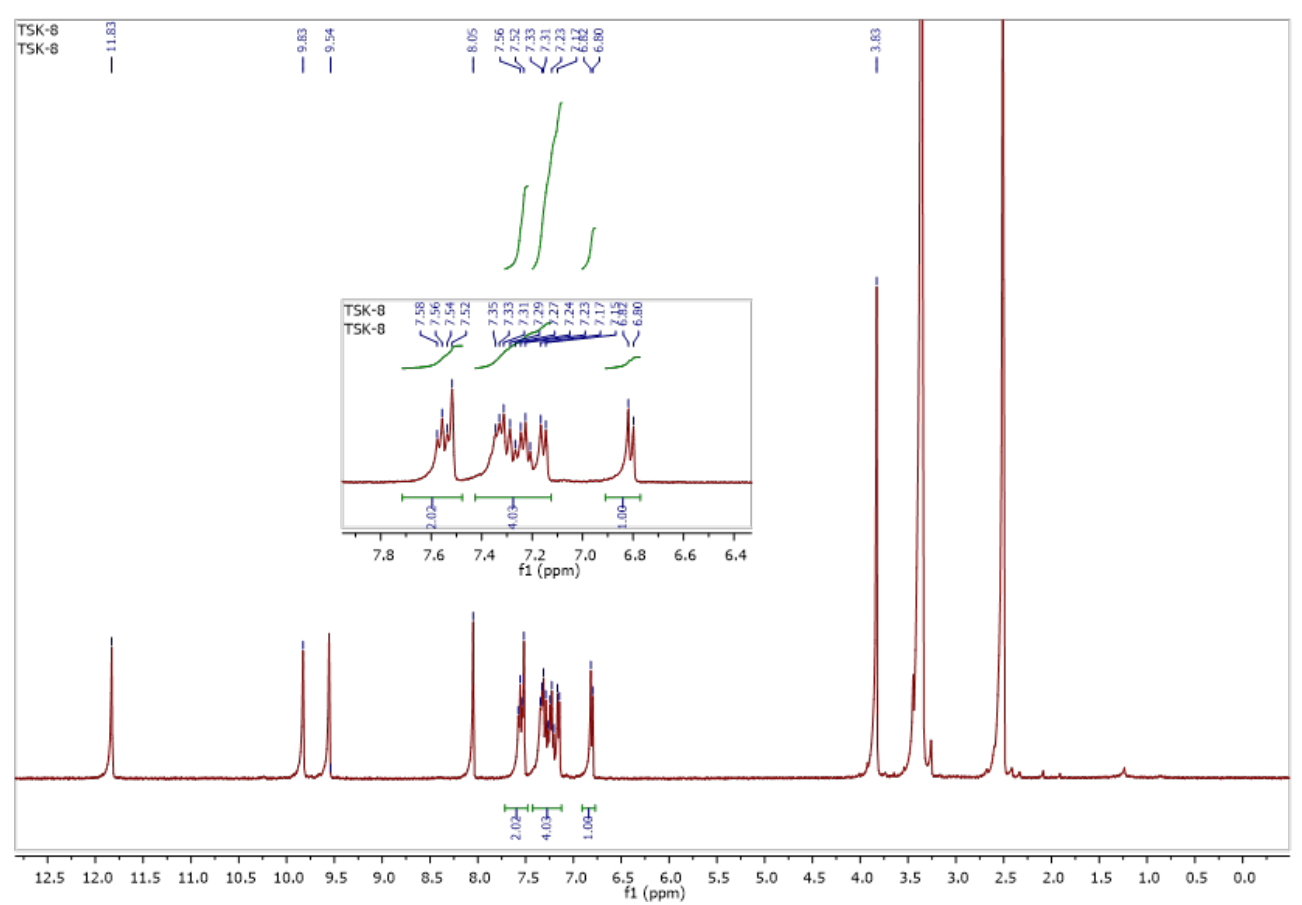

Fig 2. H-NMR of CdL complex in DMSO- $d_{6}$ solvent

\section{IR Spectra of the Ligand and Complexes}

The IR spectra of the synthesized complexes in CsI were compared with that of the azo dye. The spectra of the complexes showed the absorption bands characteristic of the ligand with some differences ascribed to the formation of respective ion associated, which showed the more characteristic infrared spectral bands of the free ligand and its complexes. The broad absorption at $3500 \mathrm{~cm}^{-1}$ is assigned to $-\mathrm{OH}$ of coumarin azo ligand. The strong band at 1651 is associated to $-\mathrm{C}=\mathrm{O}$ of chromene ring while the strong band at $1623 \mathrm{~cm}^{-1}$ is associated with $-\mathrm{CH}=\mathrm{CH}-$ of aromatic and - rings respectively $[12,15]$ as given in Fig. 3. The appearance of new band at $1477 \mathrm{~cm}^{-1}$ confirms the formation of azo $-\mathrm{N}=\mathrm{N}-$ moiety. The remarkable changes 


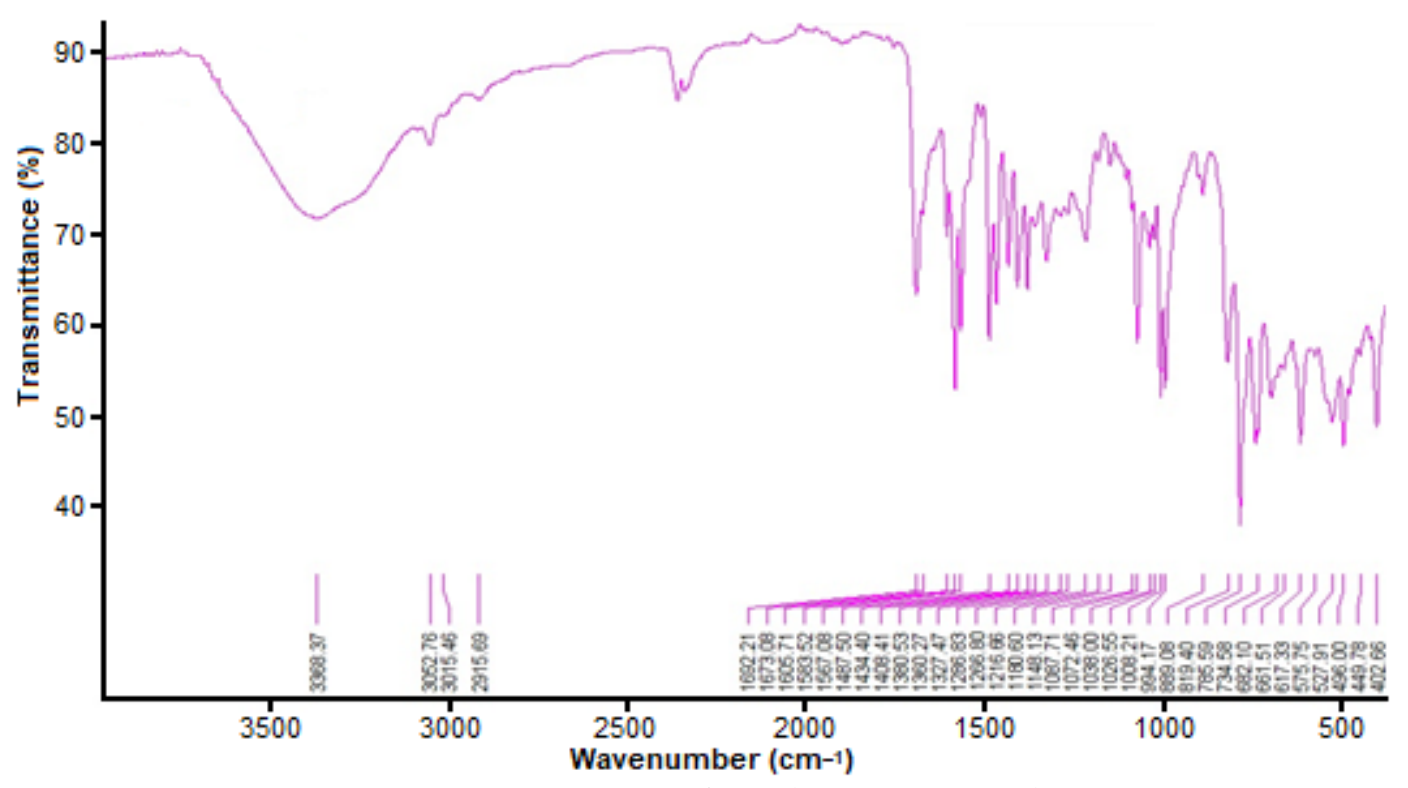

Fig 3. FT-IR spectrum of azo dye, $\mathrm{HL}$ in $\mathrm{KBr}$ disc

on $-\mathrm{N}=\mathrm{N}-$ to lower frequencies at $1450-1433 \mathrm{~cm}^{-1}$ confirm the coordination of ligand via nitrogen atom with $\mathrm{M}-\mathrm{N}$ formation beside the $-\mathrm{C}=\mathrm{O}$ shift and supports the bi dentate neutral ligand behavior as shown in Fig. 3. The vanadyl complex in Fig. 4 exhibits new band at 950.633 and $590 \mathrm{~cm}^{-1}$ confirming $\mathrm{V}=\mathrm{O}$ and $\mathrm{V}-\mathrm{N}$ bands [14-17].

\section{Electronic Spectra and Magnetic Susceptibility}

The azo ligand showed one strong absorption around $379 \mathrm{~nm}$ which was assigned to intra-ligand charge transfer of $-\mathrm{N}=\mathrm{N}-$ moiety, then confirms the formation of azo dye due to the high intensity band located near the visible region. On comparison the UV-Visible spectra of all complexes with the spectrum of the free ligand in DMSO solvent, it is noted that the new weak bands observed at around (490-380) $\mathrm{nm}$ are consistent with the chelation of empty orbitals of $\mathrm{Hg}$ (II), $\mathrm{Zn}$ (II), Cd(II) and V(IV) ions [18-19] with the lone pairs of the donating atoms in the active sites of azo dye. The intraligand charge transfer of $-\mathrm{N}=\mathrm{N}-$ moiety was shifted to longer or shorter wavelengths due to the linkage of lone

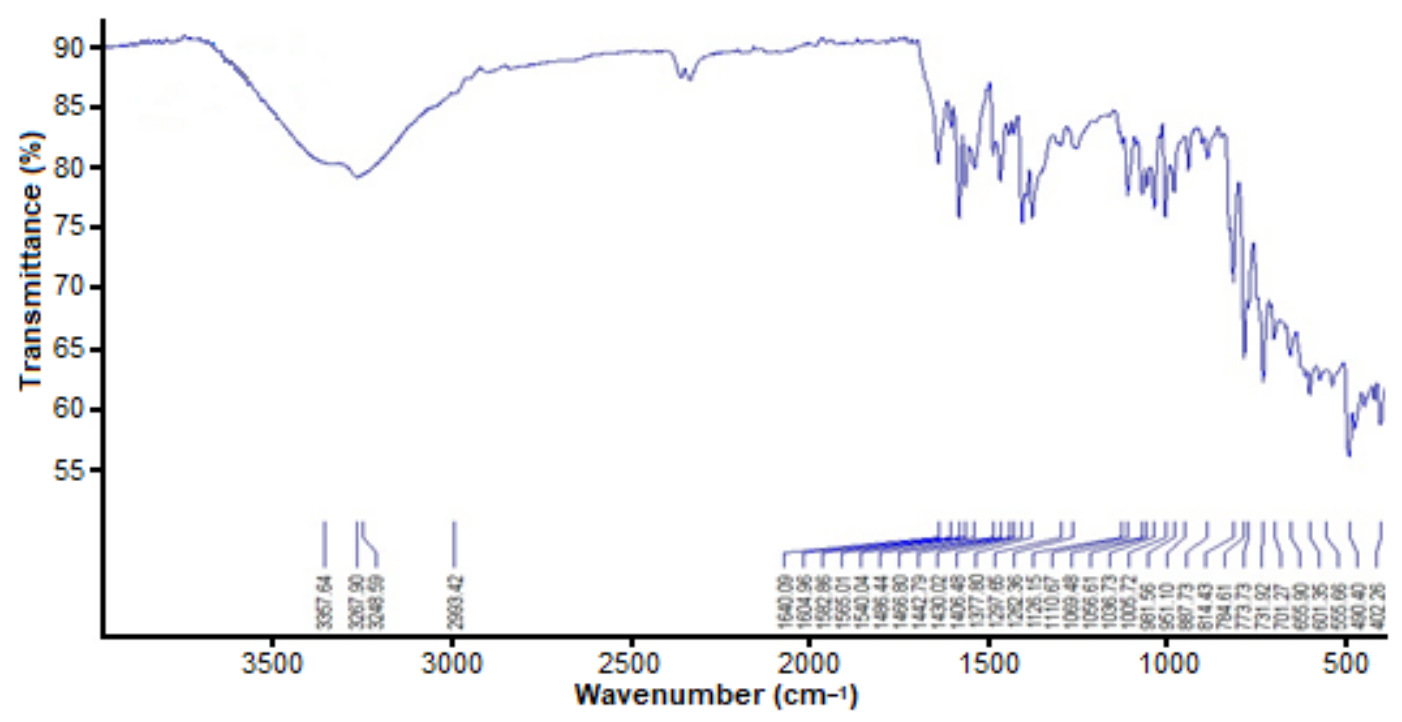

Fig 4. FT-IR spectrum of VOL complex in CsI disc 
pair to the empty orbitals of metal ions in the region (380500) $\mathrm{nm}$, Table 2. The diamagnetic properties of zinc (II), cadmium (II) and mercury(II) complexes with the association of elemental analyses confirm the tetrahedral environment. The red solution of vanadium (IV) complex displayed two spin-allowed peaks at 650 and $490 \mathrm{~nm}$ that are attributed to ${ }^{2} \mathrm{~A}_{1} g \rightarrow{ }^{2} \mathrm{~B}_{1} g$ and ${ }^{2} \mathrm{~A}_{1} g \rightarrow{ }^{2} \mathrm{~B}_{2} \mathrm{~g}$ transitions respectively [20]. The value of magnetic moment of solid complex of vanadium(II) at $27^{\circ} \mathrm{C}$ to $1.80 \mathrm{BM}$ revealed the presence of unpaired electron in its outer level $3 \mathrm{~d}^{1}$ and make it forms the possibility of five-coordinate complex with a bi dentate azo-dye ligand through two active site $\mathrm{N}=\mathrm{N}$ and $-\mathrm{OH}$ groups [18-19].

\section{Thermal Analysis of C1 and C2 Complexes}

The thermal stability of zinc(II) and cadmium(II) complexes was screened with TG-DTA analyses in the nitrogen atmosphere and presented in Table 3. The losing of weak points like $\mathrm{M}-\mathrm{Cl}$ and methyl groups were shown in the first stages of analyses at range (190-270) ${ }^{\circ} \mathrm{C}$ temperature while the final stage of analysis for $\mathrm{C} 1$ complex was accomplished at $(300-450){ }^{\circ} \mathrm{C}$ to give the stable phase of zinc(II) oxide [20]. As well as the hydrated cadmium(II) complex showed three stages of thermal analysis with losing of crystalline water at around (160-280) ${ }^{\circ} \mathrm{C}$. The data observed from weight loss $(\% \mathrm{w})$ would be in agreement with the theoretical data

Table 2. Electronic spectra and molar extinction coefficients for complexes

\begin{tabular}{|c|c|c|c|c|c|}
\hline Compounds & Molar Conc. & $\mathrm{nm} \lambda$ & $\Sigma_{\mathrm{o}} \mathrm{L} \cdot \mathrm{mol}^{-1} \mathrm{~cm}^{-1}$ & Assignment & $\mu(\mathrm{BM})$ \\
\hline \multirow{3}{*}{ VOL } & \multirow{3}{*}{$1 \times 10^{-3}$} & 655 & 110 & ${ }^{2} \mathrm{~A}_{1} \mathrm{~g} \rightarrow{ }^{2} \mathrm{~B}_{1} \mathrm{~g}$ & \multirow{3}{*}{1.80} \\
\hline & & 490 & 90 & ${ }^{2} \mathrm{~A}_{1} \mathrm{~g} \rightarrow{ }^{2} \mathrm{~B}_{2} \mathrm{~g}$ & \\
\hline & & 380 & 2900 & LMCT & \\
\hline \multirow{3}{*}{$\mathrm{ZnL}$} & \multirow{3}{*}{$1 \times 10^{-4}$} & 455 & 8000 & MLCT & \multirow{3}{*}{ Dia } \\
\hline & & 390 & 27000 & INCT & \\
\hline & & 280 & 13000 & $\pi \rightarrow \pi^{*}$ & \\
\hline \multirow{3}{*}{$\mathrm{CdL}$} & \multirow{3}{*}{$1 \times 10^{-5}$} & 500 & 20000 & INCT & \multirow{3}{*}{ Dia } \\
\hline & & 470 & 12700 & MLCT & \\
\hline & & 250 & 3000 & $\pi \rightarrow \pi^{*}$ & \\
\hline \multirow{2}{*}{$\mathrm{HgL}$} & \multirow{2}{*}{$1 \times 10^{-5}$} & 455 & 11700 & MLCT & \multirow{2}{*}{ Dia } \\
\hline & & 300 & 10000 & INCT & \\
\hline
\end{tabular}

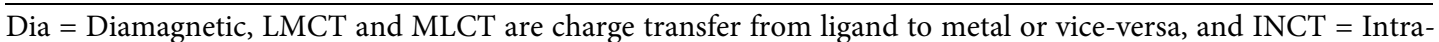
ligand charge transfer bands

Table3. Thermo gravimetric analysis (TGA) of the metal complexes

\begin{tabular}{|c|c|c|c|c|c|}
\hline \multirow[t]{2}{*}{ No. } & \multirow{2}{*}{$\begin{array}{l}\text { Molecular } \\
\text { formula }\end{array}$} & \multirow{2}{*}{$\begin{array}{l}\text { Temp. } \\
\text { range }\left({ }^{\circ} \mathrm{C}\right)\end{array}$} & \multicolumn{2}{|c|}{ Mass loss\% } & \multirow[t]{2}{*}{ Assignment } \\
\hline & & & Found & Calc. & \\
\hline \multirow{3}{*}{$\mathrm{C} 1$} & \multirow{3}{*}[\mathrm{ZnL}_{2}]{} & $190-270$ & 6.43 & 8.66 & Loss of $\mathrm{Cl}$ and $-\mathrm{OH},-2 \mathrm{OCH}_{3}$ \\
\hline & & $300-450$ & 33.84 & 3160 & $\begin{array}{l}\text { Further dissociation of the organic ligand }\left(\mathrm{C}_{8} \mathrm{H}_{6} \mathrm{~N}_{2}\right) \text { with } \\
\text { formation of } \mathrm{ZnO}+\mathrm{Zn}_{3} \mathrm{~N}_{2} \text { as final product }\end{array}$ \\
\hline & & $160-280$ & 16.01 & 17.08 & \\
\hline \multirow{4}{*}{$\mathrm{C} 2$} & \multirow{4}{*}[\mathrm{CdL}_{2}]{$\cdot 2 \mathrm{H}_{2} \mathrm{O}$} & $290-390$ & 10.06 & 9.14 & Loss of 2 hydrated $\mathrm{H}_{2} \mathrm{O}$ molecules, $-\mathrm{OCH}_{3}$ \\
\hline & & $400-560$ & 52.13 & 52.26 & $\begin{array}{l}\text { Loss of phenyl, } 2 \mathrm{Cl} \text { anion and decomposition of the organic } \\
\left(2 \mathrm{C}_{6} \mathrm{H}_{7} \mathrm{~N}_{2} \mathrm{O}\right)\end{array}$ \\
\hline & & $441-541$ & 15.16 & 14.25 & Loss of $\left(\mathrm{C}_{6} \mathrm{H}_{5} \mathrm{CH}_{3}\right)$ \\
\hline & & $541-930$ & 6.16 & 5.43 & $\begin{array}{l}\text { Further dissociation of the organic ligand }(2 \mathrm{C}) \text { with } \\
\text { formation of } \mathrm{CdO} \text { as final product }\end{array}$ \\
\hline
\end{tabular}

Bayader Fathil Abass et al. 


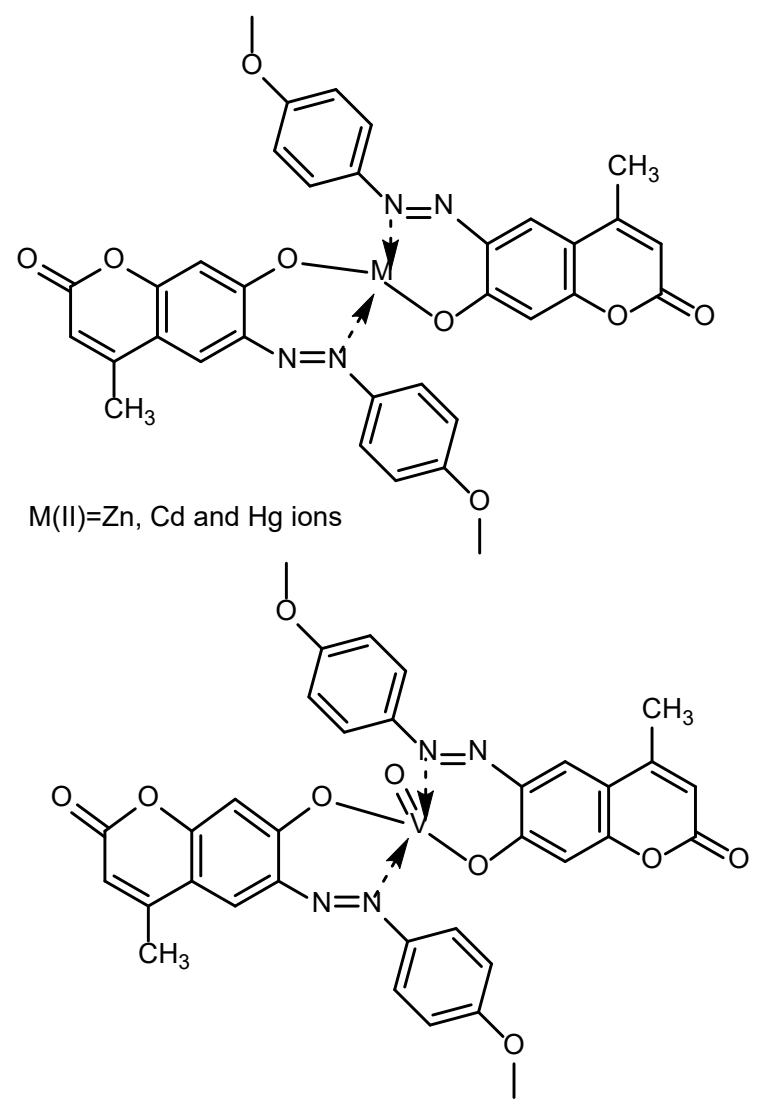

Scheme 2. Structures of metal complexes

and supports their structures [21-22].

\section{- CONCLUSION}

According to the results obtained from elemental analyses, FT-IR, NMR and EI-MS spectra and electronic spectra in ethanol and DMSO solvents, the tetrahedral geometry was identified for zinc(II), cadmium(II) and mercury(II) complexes, while the vanadium(IV) complex was square-pyramid of five coordination number via optimization the mole ratios 2:1 of ligand azo to the metal ion. The thermal analyses and molar conductivity measurements confirmed the square-pyramid around vanadium(IV) ion and tetrahedral environment around zinc(II), cadmium(II) and mercury(II) ions, Scheme 2.

\section{- ACKNOWLEDGMENTS}

Authors are so grateful for service laboratories at Mustansiriyah University, College of Science, Department of Chemistry facilitating of FT-IR, UVVisible spectra and magnetic moments measurements. As well as the authors appreciated the role of University of Baghdad, Ibn-Haitham Education College for pure sciences for carrying out the thermal analyses.

\section{- REFERENCES}

[1] Gao, P., Tsao, H.N., Yi, C., Grätzel, M., and Nazeeruddin, M.K., 2014, Extended $\pi$-bridge in organic dye-sensitized solar cells: The longer, the better?, Adv. Energy Mater., 4 (7), 1301485.

[2] Tsuzuki, K., and Tada, M., 1986, The syntheses of pteridin-2-one derivatives from diaminomaleonitrile (DAMN), J. Heterocycl. Chem., 23 (5), 1299-1301.

[3] Ayare, N.N., Ramugade, S.H., and Sekar, N., 2019, Photostable coumarin containing azo dyes with multifunctional property, Dyes Pigm., 163, 692-699.

[4] Tathe, A.B., and Sekar, N., 2016, Red emitting coumarin-azo dyes: Synthesis, characterization, linear and non-linear optical propertiesexperimental and computational approach, $J$. Fluoresc., 26 (4), 1279-1293.

[5] Matsumura, K., Yoshizaki, S., Maitani, M.M., Wada, Y., Ogomi, Y., Hayase, S., Kaiho, T., Fuse, S., Tanaka, H., and Takahashi, T., 2015, Rapid synthesis of thiophene-based, organic dyes for dyesensitized solar cells (DSSCs) by a one-pot, fourcomponent coupling approach, Chem. Eur. J., 21 (27), 9742-9747.

[6] Sahoo, J., and Paidesetty, S.K., 2015, Biological evaluation and spectral characterization of 4hydroxy coumarin analogues, J. Taibah Univ. Med. Sci., 10 (3), 306-319.

[7] Cigáň, M., Donovalová, J., Szöcs, V., Gašpar, J., Jakusová, K., and Gáplovský, A., 2013, 7(Dimethylamino)coumarin-3-carbaldehyde and its phenylsemicarbazone: TICT excited state modulation, fluorescent $\mathrm{H}$-aggregates, and preferential solvation, J. Phys. Chem. A, 117, 48704883.

[8] Wang, S., Shen, S., and Xu, H., 2000, Synthesis, spectroscopic and thermal properties of a series of azo metal chelate dyes, Dyes Pigm., 44 (3), 195-198.

[9] Refat, M.S., EI-Sayed, M.Y., and Adam, A.M.A., 2013, $\mathrm{Cu}(\mathrm{II}), \mathrm{Co}(\mathrm{II})$ and $\mathrm{Ni}(\mathrm{II})$ complexes of new Schiff 
base ligand: Synthesis, thermal and spectroscopic characterizations, J. Mol. Struct.,1038, 62-72.

[10] Sahoo, J., Mekap, S.K., and Paidesetty, S.K., 2015, Synthesis, spectral characterization of some new 3heteroaryl azo 4-hydroxy coumarin derivatives and their antimicrobial evaluation, J. Taibah Univ. Sci., 9 (2), 187-195.

[11] Satyanarayana, B., Muralikrishna, P., Kumar, D.R., and Ramachandran, D., 2013, Preparation and biological evaluation of phenothiazine derivatives, $J$. Chem. Pharm. Res., 5 (5), 262-266.

[12] Chetioui, S., Zouchoune, B., Merazig, H., Bouaoud, S.E., Rouag, D.A., and Djukic, J.P., 2021, Synthesis, spectroscopic characterization, crystal structure and theoretical investigation of two azo-palladium(II) complexes derived from substituted (1-phenylazo)2-naphtol, Transition Met. Chem., 46, 91-101.

[13] Al-Jibouri, M.N., 2014, Synthesis and characterization of transition metal complexes with Azop ligand derived from 4-hydroxy-6-methyl-2pyranone, Eur. Chem. Bull., 3 (5), 447-451.

[14] Freedman, D.A., Keresztes, I., and Asbury, A.L., 2002, Metal-coumarin complexes: Synthesis and characterization of 7-isocyanocoumarin ligands and $\mathrm{Mo}(\mathrm{CO})_{4}(7$-isocyanocoumarin $) 2$ complexes. X-ray crystal structure of $\mathrm{Mo}(\mathrm{CO})_{4}(7$-isocyano-4trifluoromethylcoumarin) $)_{2}$, J. Organomet. Chem., 642 (1), 97-106.

[15] Geary, W.J., 1971, The use of conductivity measurements in inorganic solvents for the characterization of coordination compounds, Coord. Chem. Rev., 7 (1), 81-122.

[16] Nithya, P., Rajamanikandan, R., Simpson, J., Ilanchelian, M., and Govindarajan, S., 2018, Solvent assisted synthesis, structural characterization and biological evaluation of cobalt(II) and nickel(II) complexes of Schiff bases generated from benzyl carbazate and cyclic ketones studies, Polyhedron, 145, 200-217.

[17] Al-Hamdani, A.A.S., and Al Zoubi, W., 2015, New metal complexes of N3 tridentate ligand: Synthesis, spectral studies, and biological activity, Spectrochim. Acta, Part A, 137, 75-89.

[18] Silverstein, R.M., Webster, X.F., and Kiemle, D.J., 2005, Spectrometric Identification of Organic Compounds, $7^{\text {th }}$ Ed., John Wiley \& Son, Inc., Hoboken, New York.

[19] Lu, L., Wang, J., Chen, F., Wei, L.T., Lin, L.M., Li, B.H., Singh, A., and Kumar, A., 2019, Structures and photocatalytic performance of two $\mathrm{d}^{10}$ metalbased coordination polymers containing mixed building units, Transition Met. Chem., 44 (2), 107114.

[20] Esmaeilzadeh, M.A., 2019, Composite prepared from a metal-organic framework of type MIL$101(\mathrm{Fe})$ and morin-modified magnetite nanoparticles for extraction and speciation of vanadium(IV) and vanadium(V), Microchim. Acta, 186, 14.

[21] Kostova, I., Bhatia, S., Grigorov, P., Balkansky, S., Parmar, V.S., Prasad, A.K., and Saso, L., 2011, Coumarins as antioxidants, Curr. Med. Chem., 18 (25), 3929-3951.

[22] Białek, M., Fryga, J., Spaleniak, G., and Żołnowska, M., 2017, Synthesis and olefin homo- and copolymerization behavior of new vanadium complexes bearing [OSSO]-type ligands, React. Kinet., Mech. Catal., 122 (1), 259-273. 